\title{
INTEGRAÇÃO DA INFRAESTRUTURA VERDE NO ORDENAMENTO DA CIDADE DE LICHINGA: POTENCIALIDADES E CONDICIONANTES
}

\author{
INTEGRATION OF GREEN INFRASTRUCTURE IN THE LICHINGA'S CITY PLANNING: \\ POTENTIALITIES AND CONDITIONINGS
}

\author{
Júlio Ambrósio Masquete \\ Goldfredy Manuel Chitile Chande
}

\section{Resumo}

A produção do espaço nas cidades moçambicanas é caracterizada pela supressão progressiva das áreas verdes, diante da arborização urbana inexistente ou inadequada. A partir do enfoque qualitativo, guiado pela consulta bibliográfica e documental na observação direta e do uso de recursos cartográficos, o artigo debruça sobre as potencialidades e possibilidades da integração da Infraestrutura Verde como estratégia de ordenamento e desenvolvimento do território, centrado no contexto do Município da Cidade de Lichinga (Moçambique). Considera-se importante inserir a Infraestrutura Verde no planeamento das cidades para possibilitar maior qualidade de vida, podendo constituir uma alternativa para mitigar a degradação da paisagem urbana, além de proporcionar serviços ambientais essenciais para a sustentabilidade das cidades e resiliência das comunidades. Daqui reside a importância de uma abordagem de planeamento e gestão do território que a partir de um enfoque colaborativo prioriza a delimitação de áreas para implantação da Infraestrutura Verde, entendido como fator de ordenamento do território e desenvolvimento do município. A delimitação das áreas para implantação da Infraestrutura Verde deverá observar as características da base biofísica do território e levar em consideração os problemas ambientais prevalecentes, bem como os interesses e preocupações dos segmentos da população.

Palavras-chave: Infraestrutura Verde. Ordenamento do território. Gestão territorial. Abordagem colaborativa. Expansão urbana.

\section{Abstract}

The rapid growth of "urban expansion" of Mozambican cities is characterized by the effacement of green areas, in the face of inexistent or inappropriate urban afforestation. This article was based on a qualitative approach, focusing on the potentialities and possibilities of Green Infrastructure for territory ordination and development strategy, looking at the context of Lichinga Municipality (Mozambique). Is important to insert Green Infrastructure in the city planning to improve the quality of life, being an alternative to mitigate the degradation of the urban landscape, besides of providing essential environmental services for the sustainability of cities and the resilience of communities. Hence, the importance of territory managing and planning approach which from a collaborative approach, prioritizes areas for the implementation of Green Infrastructure, understood as a factor of spatial planning and development of the municipality. The delimitation of areas for the implementation of green infrastructure should observe the characteristics of the biophysical base of the territory, taking into account the prevailing environmental problems, as well as meeting the interests and concerns of segments of the population.

Keywords: Green Infrastructure. Territorial Planning. Territorial management. Collaborative approach. Urban expansion. 


\section{INTRODUÇÃO}

Assume-se como premissa que estratégias sustentáveis de ordenamento do território devem incluir mecanismos de orientação da edificação guiados pela conservação de áreas com funções ecológicas fundamentais, nomeadamente áreas naturais, áreas verdes e áreas com potencial produtivo e de risco ambiental.

As cidades moçambicanas são caracterizadas por rápido processo de urbanização, cujo resultado da forma de produção do espaço tem sido marcado pela prevalência e reprodução da ocupação indiscriminada da base biofísica e pelo uso habitacional, especificamente, acompanhada da supressão progressiva das áreas verdes, diante da arborização urbana inexistente ou inadequada, particularmente nas áreas consideradas de "expansão urbana".

A degradação do capital natural é reconhecida como uma ameaça ao desenvolvimento sustentável do território, na medida em que influencia na reprodução de riscos ambientais e na redução da resiliência do território aos choques ambientais. Portanto, parte-se do entendimento que ainda prevalece nas cidades moçambicanas um padrão de ocupação do território que gera inúmeros problemas, físico-estruturais, ambientais e socioeconômicos, nefastos para a cidade como um todo.

Assim, é de assinalar que o crescimento desmensurado das cidades com base no adensamento construtivo e à custa do capital natural, bem como da impermeabilização intensa do solo, provoca mudanças consideráveis na qualidade do ambiente (SCHUTZER, 2012), no sentido negativo. O padrão de urbanização ao produzir formas de ocupação que apresentam componentes de insustentabilidade está proporcionando baixa qualidade de vida à população, sendo imperiosa, diante dessa realidade, a implementação de programas de políticas públicas voltadas à aumentar a resiliência das comunidades e ao desenvolvimento sustentável.

Em Moçambique, o marco legal obriga a elaboração de instrumentos de ordenamento territorial de nível autárquico, concretamente o Plano de estrutura Urbana (PEU), os Planos Gerais e Parciais de Urbanização e o Plano de pormenor (MICOA, 2009).
Contudo, dos 53 Municípios até então criados, poucos dispõem de Plano de Estrutura Urbana, desse grupo inclui-se o Município da Cidade de Lichinga.

Em observância aos objetivos e conteúdos adotados para orientar a elaboração desses instrumentos, ao nível autárquico, a existência e aplicação de um Plano de Estrutura Urbana auxiliaria profundamente na orientação e controle da ocupação do território. Assim, a falta do uso rigoroso e sistemático de instrumentos apropriados de planeamento e gestão territorial, de função preventiva, é aqui apontada como uma das causas dos problemas relacionados com a forma de ocupação do território nas cidades moçambicanas, particularmente no contexto da Cidade de Lichinga.

Perante situações que revelam ocupação de forma casuística, pouco estruturada e com deficiências funcionais, Carvalho (2018) chama a atenção para aspectos de planeamento e ordenamento do território, concretamente a importância e necessidade da definição de um conjunto de referências estruturantes que articula as suas diferentes unidades territoriais, entre as quais inclui a Infraestrutura Verde.

É diante do reconhecimento da necessidade de definição de referências estruturantes da cidade que no presente artigo propõe-se refletir por volta das seguintes questões norteadoras: Quais são os potenciais contributos da Infraestrutura Verde para o Município (com foco na Cidade de Lichinga)? Em que medida a Infraestrutura Verde constitui instrumento de ordenamento e desenvolvimento do território? Diante da ocupação indiscriminada da base biofísica, no caso concreto da Cidade de Lichinga, como o Município pode capitalizar a abordagem da Infraestrutura Verde como instrumento para orientar a forma de ocupação do território? Como instituir um processo de ordenamento e desenvolvimento urbano que contemple a Infraestrutura Verde?

Nesse sentido, a partir de um enfoque fundamentalmente qualitativo, guiado da análise bibliográfica e documental, bem como do uso dos resultados do estudo empírico, de observações de campo e uso de imagens do Google Earth, pretende-se neste artigo apresentar propostas para integração da Infraestrutura 
Verde no modelo de desenvolvimento do Município da Cidade de Lichinga (Moçambique).

\section{O Papel da Infraestrutura Verde Para O TERRITório}

Um dos grandes desafios que o processo de urbanização impõe aos decisores, e não só, reside na identificação e implementação de estratégias que incentivem o desenvolvimento urbano sustentável, é que as cidades sejam resilientes face às mudanças climáticas.O Programa das Nações Unidas para os Assentamentos Humanos (ONU-Habitat) define o planeamento urbano e territorial como um processo de tomada de decisões com o objetivo de atingir metas económicas, sociais, culturais e ambientais por meio do desenvolvimento de visões espaciais, estratégias e planos, bem como a aplicação de um conjunto de princípios políticos, ferramentas, mecanismos institucionais e de participação e procedimentos regulatórios (ONU-Habitat, 2015). A partir dessa definição, assinala-se a necessidade de identificação de respostas diante dos problemas e desafios da cidade, na perspectiva de induzir o melhor aproveitamento das potencialidades biofísicas do território. Para tal, a seleção dos instrumentos de auxílio à prossecução de determinados objetivos de desenvolvimento territorial afigura-se fundamental.

\section{Definição de Infraestrutura Verde}

A partir de Ferreira e Machado (2010), a Infraestrutura Verde é definida como uma rede de áreas naturais e áreas abertas (open spaces) fundamentais para o funcionamento ecológico do território.

Franco (2010) inclui na sua definição a interconexão entre as "componentes verdes" como elemento essencial da Infraestrutura Verde, da qual define a Infraestrutura Verde como uma rede interconectada de áreas verdes naturais e outros espaços abertos que conservam valores e funções ecológicas. Reafirma-se nessa definição que a ligação ou conectividade entre as zonas "naturais" constitui um atributo fundamental do conceito de Infraestrutura Verde, o que pressupõe a necessidade de análise das interações espaciais entre as diferentes utilizações da terra no território como recurso metodológico para a sua delimitação e implantação.

A União Europeia dispõe da Estratégia para a Infraestrutura Verde. Neste documento a Infraestrutura Verde é definida como uma rede de zonas naturais e seminaturais estrategicamente planeadas, concebida e gerida para prestar uma ampla gama de serviços ecossistêmicos, que incorporam espaços verdes (ou azuis, se envolver ecossistemas aquáticos) e outras características físicas em zonas terrestres (incluindo as costeiras) e marinhas (COMISSÃO EUROPEIA, 2019). Daqui se acresce à importância da configuração espacial, o que pressupõe que a implantação da Infraestrutura Verde exige ser estrategicamente planeada.

Portanto, das definições apresentadas, entende-se que a Infraestrutura Verde trata-se fundamentalmente de uma rede planeada e interconectada de áreas verdes. A considerar a localização e a interconexão entre as componentes verdes como um fator fulcral a ser considerado no ordenamento do território. Ademais, o conceito de Infraestrutura Verde está associado à conservação e à valorização do capital natural do território e, por conseguinte, garante a proteção dos sistemas naturais de maior fragilidade e dos espaços de elevado valor ecológico.

\section{Serviços ambientals Integrados À INFRAESTRUTURA VERDE}

Ao longo do tempo diversas abordagens teórico-metodológicas enalteceram (e enaltecem) a integração das áreas verdes nas políticas territoriais da cidade. Identifica-se alguns modelos de desenho urbano que valorizam e integram as áreas verdes: a proposta do Urbanismo Moderno, consubstanciado na Carta de Atenas e que tem como seu expoente máximo o Le Corbusier; as propostas das cidades-jardins de Ebenezer Howard; os modelos apresentados por Lewis Mumford; o atual paradigma de Cidades Verdes (Green cities); entre outros.

Concretamente, o modelo territorial de Le Corbusier incluía o desenvolvimento de áreas verdes em zonas denominadas "cinturão da cidade" ou em áreas consideradas prioritariamente não adequadas 
para o uso habitacional, no exemplo de áreas "deprimidas" e húmidas ou junto à drenagem natural.

Ebenezer Howard valorizou uma cidade que capitaliza os benefícios que existem no campo, a partir do fortalecimento de áreas verdes e da conservação do cinturão de campo ou jardim em volta das cidades, onde matas, bosques, além de jardins e parques, ficariam a poucos minutos da área residencial.

Lewis Mumford defendia a integração da matriz verde nas políticas territoriais da cidade, em observância à sua função social e biológica, bem como para atender as particularidades socioeconómicas dos vários segmentos da população, ao que incluía reservar determinadas áreas dedicadas ao uso agrícola.

Mais recentemente, assinala-se o modelo de organização territorial de cidade proposto por Jorge Carvalho, no qual valoriza a integração de percursores verdes ao defender a prevalência da cidade campestre. Os Percursores Verdes correspondem a contínuos verdes que poderão constituir corredores ecológicos, penetrando e estruturando a cidade, que na perspectiva de Jorge Carvalho devem ser assumidas como áreas non aedificandi. Portanto, Carvalho encara as estruturas verdes numa perspectiva de património, com o seu valor simbólico, pedagógico e ambiental, e também económico, enquanto oferta de lazer e de turismo. A partir dessa visão, destaca um conjunto de atividades que podem ser desenvolvidas nos percursores verdes, no exemplo de organização de trabalhos de campo, desenvolvimento de um nicho de mercado de agricultura biológica, criação de hortas urbanas e a exploração florestal (CARVALHO, 2000).

O paradigma das cidades verdes (Green cities) inclui a valorização de espaços verdes da cidade como necessárias para a promoção da sustentabilidade socioeconómica e ambiental, estando também o conceito de "cidades verdes" associado a cidades resilientes e autossuficientes.

Do anteriormente apresentado, observa-se que a integração das áreas verdes nos modelos territoriais de cidade esteve associada à valorização da conservação do capital natural do território, em observância aos benefícios provenientes dos serviços ambientais, como também do reconhecimento das funções socioeconômicas associadas.

Schutzer destaca particularmente os benefícios da vegetação arbórea em relação aos processos naturais para a cidade, entre os quais se destaca:

- A preservação dos recursos hídricos, no exemplo da preservação do lençol freático e da qualidade da água, ao favorecer a retenção da poluição causada pelas atividades antrópicas;

- A preservação e melhoria das condições climáticas, com realce para o equilíbrio da umidade do ar, a estabilização da temperatura ou redução do efeito das ilhas-de-calor e filtração do ar por meio da retenção da poeira;

- A preservação e a melhoria das condições do solo, do qual se assinala a proteção contra a erosão e contra o assoreamento, a manutenção ou melhoria da fertilidade do solo através da intensificação da vida biológica e da formação da camada orgânica superficial, bem como a proteção de encostas e vertentes através da estabilização do solo pelas raízes;

- A preservação da biodiversidade, concretamente a partir do combate a supressão ou escassez do verde, ao que corresponde o fortalecimento da arborização, cuja importância reside também no favorecimento da existência de nichos diferenciados, tanto para a fauna como para a própria flora, além da sua função de produção de alimentos;

- A vegetação arbórea desempenha também os benefícios voltados à integração social, concretamente como áreas de lazer; e à melhoria das condições paisagísticas e de conforto urbano e de estímulo à saúde psíquica da sociedade (SCHUTZER, 2012).

Particularmente, assinala-se a contribuição da infraestrutura verde para o desempenho das funções rurais, assim como para a promoção de cidades resilientes e sustentáveis.

A abordagem da Infraestrutura Verde é enquadrada nas soluções baseadas na natureza, cujos contributos resultantes da sua introdução e utilização residem no aumento da biodiversidade na cidade, 
uma maior resiliência frente às mudanças climáticas $\mathrm{e}$, ao mesmo tempo, proporciona benefícios sociais e económicos para as pessoas e sociedade como um todo (HERZOG, RIZZI E FERRAZ, 2021).

Como uma abordagem com influência na resiliência territorial, a infraestrutura verde responde ao problema da ocupação desordenada e casuística, com realce para a redução da vulnerabilidade aos riscos decorrentes da inundação, através dos serviços providos pelo ecossistema. É diante desse reconhecimento que, no contexto de Portugal, a Direção-Geral do Território (2016:78) aponta que "será necessário aumentar a resiliência das zonas urbanas e periurbanas e garantir os serviços dos ecossistemas, sendo, para esse efeito, necessário, entre outros aspectos, estabilizar, desenvolver e implementar o conceito de infraestrutura verde".

Valoriza-se a não menorização das funções rurais na cidade e, assim, assume-se as áreas com funções agrícolas e florestais como integrantes da cidade, ao que se corrobora com a necessidade de ordená-las, o que implica que lhes sejam atribuídas funções específicas, contrariando a simples atitude expectante de futura edificabilidade (CARVALHO, 2012).

Portanto, do anteriormente exposto, observa-se que a implementação da abordagem da Infraestrutura Verde possibilita "Viabilizar sistemas de ocupação e uso do solo visando à conservação das áreas com potencialidades produtivas, por um lado, e a conservação da natureza e biodiversidade, por outro, bem como o correto ordenamento do espaço rústico" (DIREÇÃO-GERAL DO TERRITÓRIO, 2016:60).

Os espaços verdes da cidade, como parques, praças e ruas arborizadas, são exemplos de tipologias de Infraestrutura Verde que fornecem serviços ambientais relacionados ao bem-estar da população, ao equilíbrio ambiental, à proteção dos recursos hídricos e do solo e à conservação da biodiversidade.

Em observância aos potenciais benefícios gerados pela implantação da Infraestrutura Verde, Solera et al. (2020) identifica 4 (quatro) categorias de serviços ambientais, nomeadamente:

- Provisão: a capacidade dos ecossistemas em prover bens, alimentos, matéria-prima para a geração de energia, fibras, fitofár- macos, recursos genéticos e bioquímicos, plantas ornamentais e água;

- Regulação: benefícios obtidos a partir de processos naturais que regulam as condições ambientais que sustentam a vida humana, no exemplo da purificação do ar, regulação do clima, purificação e regulação dos ciclos das águas, controle de enchentes e de erosão, tratamento de resíduos, desintoxicação e controle de pragas e doenças;

- Culturais: relacionados com a importância dos ecossistemas em oferecer benefícios associados à recreação, educacionais, estéticos e espirituais e manutenção de habitat;

- Suporte: processos naturais necessários para que os outros serviços existam, como a ciclagem de nutrientes, a produção primária, a formação de solos, a polinização e a dispersão de sementes.

A descrição dos potenciais serviços ambientais da Infraestrutura Verde concorre para levantar a "polivalência" ou multifuncionalidade que pode ser gerada pela sua implantação. Para Austin (2014), a multifuncionalidade da implantação da Infraestrutura Verde está associada à possibilidade de atender muitos problemas da cidade, simultaneamente, o que lhe confere eficiência e economia.

A implantação da Infraestrutura Verde na cidade é apontada por reunir múltiplos benefícios, destacando-se: sua importância para a saúde da comunidade, o combate à exclusão social, a possibilidade de influenciar na integração rural-urbano na cidade e a amenização da temperatura de superfície.

É necessário associar o ordenamento do território às estratégias de desenvolvimento econômico e social que garantam a equidade e inclusão social. Como refere Belik (2010:113) "para garantir a inclusão, é necessário que as pessoas pobres passem a contar com uma base sobre a qual possam se sustentar". Concretamente, a definição de zonas agrícolas, como tipologia de Infraestrutura Verde, paralelamente a promoção da agricultura urbana (hortas comunitárias), voltada tanto para o autoconsumo e/ou para fins comerciais, possibilita ampliar o acesso aos alimentos, à expansão 
da produção e do consumo de alimentos saudáveis, à geração de ocupação e renda e à melhoria das condições de saúde das famílias pobres, constituindo, assim, uma oportunidade de inclusão social.

Nesse sentido, a implantação da Infraestrutura Verde pode constituir fator indutor do alcance de determinados Objetivos de Desenvolvimento Sustentável (ODS). Dentre outros, os ODS estão voltados para erradicar a pobreza, a desigualdade, a injustiça e combater as mudanças climáticas. A agricultura urbana é aqui valorizada como uma tipologia da Infraestrutura Verde.

Defende-se que a condição explícita assumida nos instrumentos de ordenamento do território quanto ao desenvolvimento da atividade agrícola no território da cidade, se autorizada, condicionada ou desencorajada, constitui a pré-condição para a promoção do uso agrícola. Assim, a integração do uso agrícola nos instrumentos de ordenamento territorial tem o potencial de garantir a segurança e posse de terra, na medida em que passa a constituir uso explicitamente admissível e, assim, reduz o medo de conversão por outros usos de terra concorrentes.

Em 2007 foi aprovada a base legal específica sobre as atividades de planeamento e ordenamento do território (a Política de Ordenamento do Território, Resolução n. ${ }^{\circ}$ 18/2007 e a Lei de Ordenamento do Território, Lei n. ${ }^{\circ}$ 19/2007). Segundo o artigo 6 da Lei de Ordenamento do Território, compete ao Estado e às Autarquias Locais promover, orientar, coordenar e monitorar de forma articulada o ordenamento do território. Embora essa Lei defina a obrigatoriedade de elaboração dos instrumentos de ordenamento territorial, grande parte dos municípios em Moçambique não dispõem planos de estrutura urbana, como é o caso do Município da Cidade de Lichinga. Portanto, embora exista um quadro legal para orientar a organização do meio físico com vista ao seu aproveitamento harmonioso e sustentável, observa-se nas cidades moçambicanas a ausência da aplicação de instrumentos de ordenamento do território, acompanhado da reprodução da ocupação espontânea e informal, particularmente em áreas susceptíveis a inundações e em encostas íngremes. Aponta-se como prováveis causas que limitam os municípios criarem planos de estrutura urbana, fundamentalmente, as limitações de caráter financeiro e a falta de recursos humanos qualificados para tal. Admite-se que a ausência de instrumentos de ordenamento do território influencia negativamente na organização do meio físico e a melhor distribuição das atividades humanas no território.

Segundo a legislação em vigor, relativa ao planeamento e ordenamento do território, e particularmente o Regulamento de Ordenamento do Território (Decreto n23/2008), o Plano de Estrutura Urbana é um dos principais instrumentos cujo objetivo está centrado em estabelecer os princípios de sustentabilidade ambiental que devem orientar a ocupação do território, bem como definir os modelos de ordenamento do território. Para tal, o Plano de Estrutura Urbana deverá integrar a identificação das zonas de proteção ambiental e das zonas de importância ecológica.

No contexto de Moçambique, no geral, e a cidade de Lichinga, em particular, entende-se que prevalecem práticas de gestão da terra guiadas pela associação do uso agrícola ao campo, e não à cidade. Com efeito, e como resultado dessa atuação, as áreas atualmente agrícolas são toleradas como expetante de futura edificabilidade. Essa realidade é influenciada porque não se dispõe de um quadro legal que integra a valorização e conservação de áreas com potencial produtivo na cidade, ao que garantiria, assim, a segurança da posse de terra e a promoção da atividade agrícola na cidade.

Sublinha-se aqui a importância da Infraestrutura Verde, na medida em que possibilita atender os objetivos preconizados pelo Plano de Estrutura Urbana, particularmente na compatibilização das áreas ecologicamente sensíveis, bem como orientar a edificação.

Por esse conjunto de justificativas, considera-se fundamental, no contexto de Moçambique como país com altos níveis de pobreza, inserir a Infraestrutura Verde no modelo de desenvolvimento territorial da cidade de Lichinga.

O quadro legal sobre planeamento e ordenamento do território de Moçambique não integra a delimitação da Infraestrutura Verde como um requisito indispensável, embora alguns conteúdos da Infraestrutura Verde estejam presentes no Plano de Estrutura Urbana. 


\section{Eleição de Áreas para Implantação da Infraestrutura Verde: Considerações Teórico-Metodológicas}

É importante inserir a Infraestrutura Verde no planeamento das cidades, na medida em que se possibilita maior qualidade de vida, podendo constituir uma alternativa para mitigar a degradação da paisagem urbana, além de proporcionar serviços ambientais essenciais para a sustentabilidade das cidades. Daqui reside a importância de uma abordagem de planeamento e gestão do território que prioriza áreas para implantação da Infraestrutura Verde como fator de ordenamento do território e desenvolvimento do município.

Como priorizar áreas para implantação da Infraestrutura Verde, entendido como fator de ordenamento do território e desenvolvimento do município?

Segundo Carvalho (2003), o ordenamento do território está centrado no aproveitamento racional dos recursos existentes (naturais, técnicos e financeiros), na defesa da qualidade de vida da população e na prossecução do interesse público do território, o que significa, necessariamente, procurar localização e articulações racionais de infraestruturas e espaços públicos, edifícios e respectivos usos.

A definição de áreas prioritárias para a implantação da tipologia de Infraestrutura Verde é um elemento importante, especificamente diante de abordagens guiadas pela racionalidade ou sustentabilidade.

Para Schutzer (2012), o processo de ocupação do território deve ser norteado pela observância do que os processos naturais sugerem. Concretamente, Schutzer identifica como áreas de incentivo a indução da evapotranspiração, mais favoráveis ao crescimento rápido e sustentável da flora, os anfiteatros e nascentes, as várzeas, as áreas próximas aos canais de drenagem (vales, mesmo não contendo planícies aluviais significativas) e encostas íngremes. Assim, esse autor considera que as áreas junto aos canais de drenagem são essenciais para a filtração do escoamento da água das chuvas e diminuição do aporte de sedimentos aos mananciais; as margens dos cursos de água como espaços considerados non aedificandi, contudo, como áreas compatíveis como espaços verdes de recreio e lazer, ao desenvolvimento da agricultura de base ecológica; e áreas com relevo plano no entorno de rios canalizados como espaços mais sujeitos a processos de inundação e alagamento.

Contrariamente ao incentivo para a localização do uso habitacional, considera-se prioritário a instalação de determinadas tipologias de Infraestrutura Verde nas áreas do entorno de córregos, rios, lagos e lagos, bem como em áreas de encostas íngremes (FERREIRA E MACHADO, 2012; SCHUTZER, 2012). Com base em Ferreira e Machado (2012); Schutzer (2012); Solera et al. (2020), sugere-se como áreas de indução para a implantação da Infraestrutura Verde, as seguintes:

- Áreas com alta susceptibilidade à inundação e à erosão;

- Áreas com déficit de vegetação nativa;

- Áreas de Preservação Permanente (APP) de cursos de água com déficit de vegetação;

- Áreas com alta taxa de impermeabilização do solo e que promovem o aumento da temperatura da superfície;

- Vias altamente movimentadas e sem árvores;

- Áreas com solo de elevado valor ecológico.

A seleção e priorização de áreas para implantação de tipologias de Infraestrutura Verde enquadra-se nas orientações da UN-Habitat, como meio para possibilitar territórios sustentáveis e comunidades resilientes. Especificamente, a partir do documento "Diretrizes Internacionais para o Planeamento Urbano e Territorial", as entidades de nível com competência no planeamento e gestão do território são cometidas a: i) definir padrões de ocupação e regulamentos voltados a proteger terras agrícolas, zonas húmidas, santuários ecológicos, espaços verdes abertos, ecossistemas e locais de biodiversidade; II) necessidade de identificar, revitalizar, proteger e produzir espaços públicos e verdes de alta qualidade, com valor ecológico ou patrimonial especial e evitar a criação de ilhas de calor; iii) proteger a biodiversidade local e apoiar a criação de espaços verdes públicos multifuncionais (UN-Habitat, 2015). 
A Agenda Estratégica Florestal de Moçambique 2019-2035 e o Programa Nacional de Florestas priorizam a promoção de ações de arborização de vias, gestão de zonas verdes e o desenvolvimento de florestas na cidade como estratégias para o aumento da resiliência às mudanças climáticas e desastres naturais (MINISTÉRIO DE TERRA, AMBIENTE E DESENVOLVIMENTO RURAL, 2019).

Portanto, do anteriormente exposto, assinala-se a necessidade e a importância de delimitar áreas prioritárias para a implantação de tipologias de Infraestrutura Verde, em observância às características da base biofísica do território, aos problemas socioambientais do território e ao atendimento dos interesses e preocupações da coletividade.

Porque a finalidade é o melhor aproveitamento da terra, assume-se que a colaboração entre uma diversidade de atores constitui imperativo para a eficaz identificação das áreas prioritárias para implantação da Infraestrutura Verde. Assim, entende-se que a delimitação da Infraestrutura Verde requer uma participação ativa de diversos atores da sociedade, como forma de estabelecer um conjunto socialmente identificado de problemas, objetivos e soluções. A consolidação de propostas colaborativas e participativas representa um mecanismo de construção de ações sustentáveis conjuntas, na medida em que envolve diagnóstico-reconhecimento-pactos-atuação.

Portanto, sugere-se que a delimitação de áreas prioritárias para a implantação da Infraestrutura Verde inclua a valorização do envolvimento ativo de uma diversidade de sujeitos sociais, com destaque para os agentes com ingerência no acesso à terra (líderes comunitários, Secretários de bairros e do Município), académicos/investigadores (geógrafos, urbanistas, planificadores territoriais etc.) e antigos residentes e influentes do bairro (com mais de dez anos de residência e idade superior a 21 anos, com conhecimento da dinâmica de ocupação do território em referência).

Portanto, a partir de Alves (2009), Ferreira e Machado (2010) e Solera et al. (2020), a delimitação colaborativa e participativa de áreas prioritárias para a implantação da Infraestrutura Verde poderia observar os seguintes passos:
- Reflexão coletiva, envolvendo uma equipe de diversos atores sociais, sobre o potencial papel da Infraestrutura Verde no município diante da dinâmica de ocupação da terra, dando ênfase ao estudo das funções e serviços ambientais por tipologia de Infraestrutura Verde;

- Descrição da situação ambiental do território, por meio de indicadores ambientais que auxiliam conhecer as áreas de incentivo a indução da evapotranspiração, ou não, dando ênfase à: identificação de áreas com alta susceptibilidade à inundação e à erosão; áreas com déficit de vegetação nativa; áreas de Preservação Permanente (APP) de cursos de água com déficit de vegetação; áreas com alta taxa de impermeabilização do solo e que promovem o aumento da temperatura da superfície; vias altamente movimentadas e sem árvores; áreas com solo de elevado valor ecológico; e áreas com vegetação nativa;

- Identificação de áreas prioritárias para a implantação da Infraestrutura Verde, visando a manutenção, recuperação ou ampliação dos serviços ambientais mais importantes no contexto municipal;

- Compreensão do Direito de Uso e Aproveitamento da Terra nas áreas identificadas como prioritárias para implantar a Infraestrutura Verde;

- Definição criteriosa dos espaços prioritários para provisão e ampliação de serviços ambientais e respectiva seleção colaborativa das tipologias de Infraestrutura Verde apropriadas, em observância à realidade do município.

Nesse sentido, esses pressupostos enquadram-se nos atuais paradigmas de planeamento e gestão do território, na medida em que enaltecem princípios democráticos com meio para oferecer uma estrutura espacial voltada a proteger e a gerenciar o ambiente natural e construído das cidades e territórios. E das orientações aqui apontadas, a delimitação e a implantação da Infraestrutura Verde possibilitam criar áreas "non aedificandi", constituído, assim, recurso para disciplinar a forma de ocupação do território e potenciar o melhor aproveitamento da terra, para além que a implementação do conceito de Infraestrutura Verde enquadra-se nas estratégias de 
aumento da resiliência da cidade aos riscos agravados pelas alterações climáticas.

\section{Do Diagnóstico Às Possibilidades de Ocupação Do TerRitório}

A cidade de Lichinga está situada no planalto do mesmo nome, na parte ocidental da província de Niassa, cuja coordenada geográfica referente à parte central da cidade é de $13^{\circ} 18^{\prime} 00$ de Latitude Sul e $35^{\circ} 14^{\prime} 45^{\prime \prime}$ de Longitude Leste. Quanto à superfície, a cidade de Lichinga ocupa uma pequena parte da província de Niassa, numa área de $258 \mathrm{~km}^{2}$, que é correspondente a $0,20 \%$ da superfície total da província de Niassa.

Segundo dados do Instituto Nacional de Estatística (INE) de Moçambique, em 2017, a população total da cidade de Lichinga era de 243.668 habitantes, contra o efetivo populacional de 142.331 habitantes, em 2007. Esses dados revelam que num período de 10 anos a cidade de Lichinga registou um crescimento absoluto

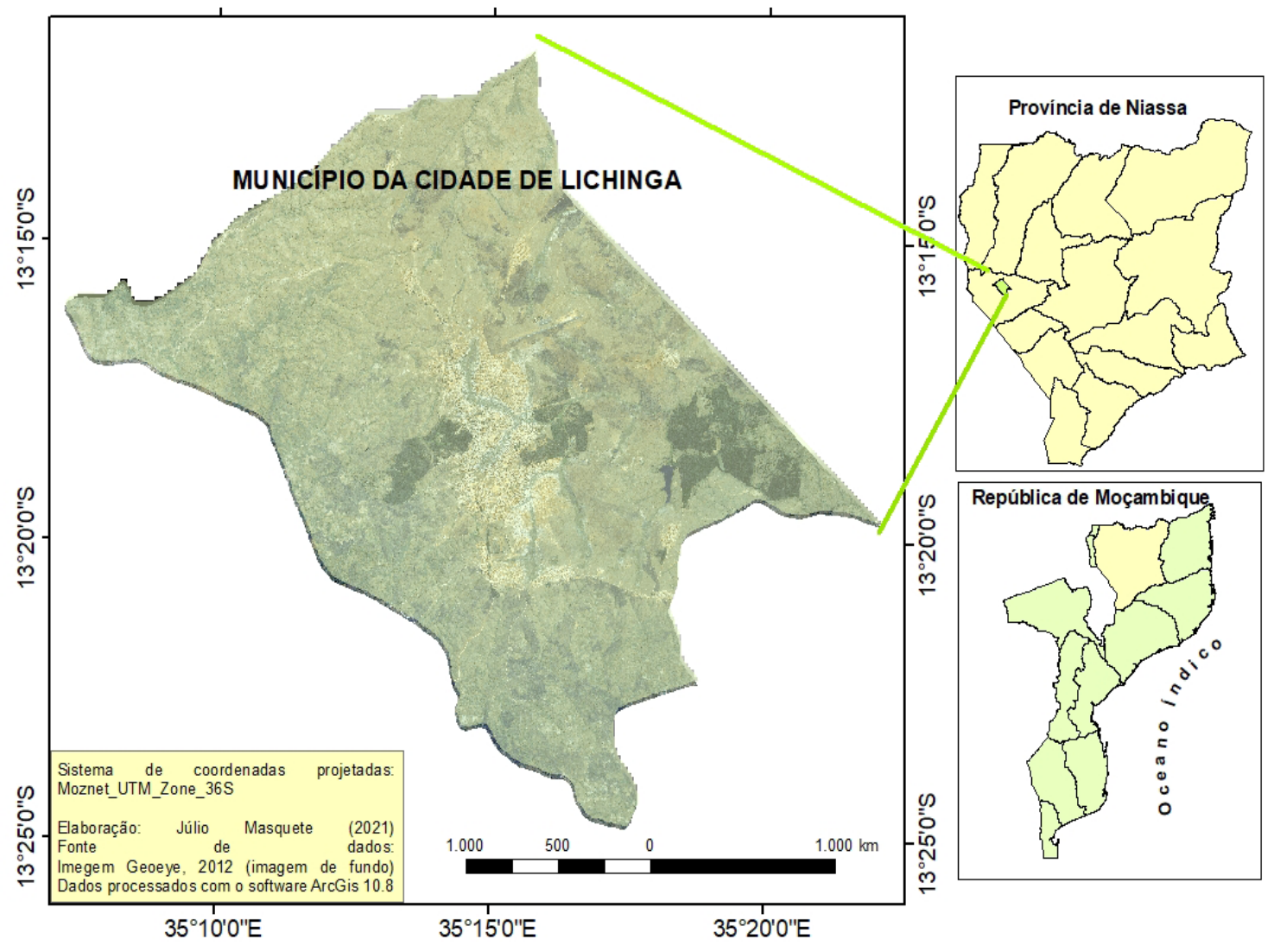

Figura 1: Localização do Município da Cidade de Lichinga.

Fonte: Elaborado pelos autores, em 2021. 
da população na ordem de 101.337 habitantes, que é correspondente a um crescimento relativo de $71 \%$. Segundo dados do INE, projeta-se que a cidade de Lichinga tenha 560.871 habitantes em 2040, portanto, mais que o dobro da população em cerca de 20 anos (INE, 2020).

Esses dados relativos ao crescimento da população no período em análise possibilitam reafirmar que um dos principais desafios para o Município da Cidade de Lichinga é identificar estratégias que atendem, de forma preventiva, as demandas da população, particularmente na forma espacial de sua ocupação.

O padrão de edificação do uso habitacional na cidade de Lichinga é predominantemente horizontal, de ocupação extensiva, cujas implicações assentam no forte aumento da demanda por parcelas de terra para atender as necessidades da população, particularmente, fenómeno característico das cidades moçambicanas. Essa realidade repercute no aumento das dificuldades administrativo-financeiras das entidades públicas para atender as necessidades básicas da população, no que diz respeito à alocação e à distribuição territorial dos serviços e infraestruturas básicas. Portanto, o prevalecente padrão extensivo de edificação apresenta largas possibilidades de acarretar disfunções na provisão de serviços e infraestrutura básica, diante das limitações financeiras que observam grande parte das entidades públicas com competência para tal.

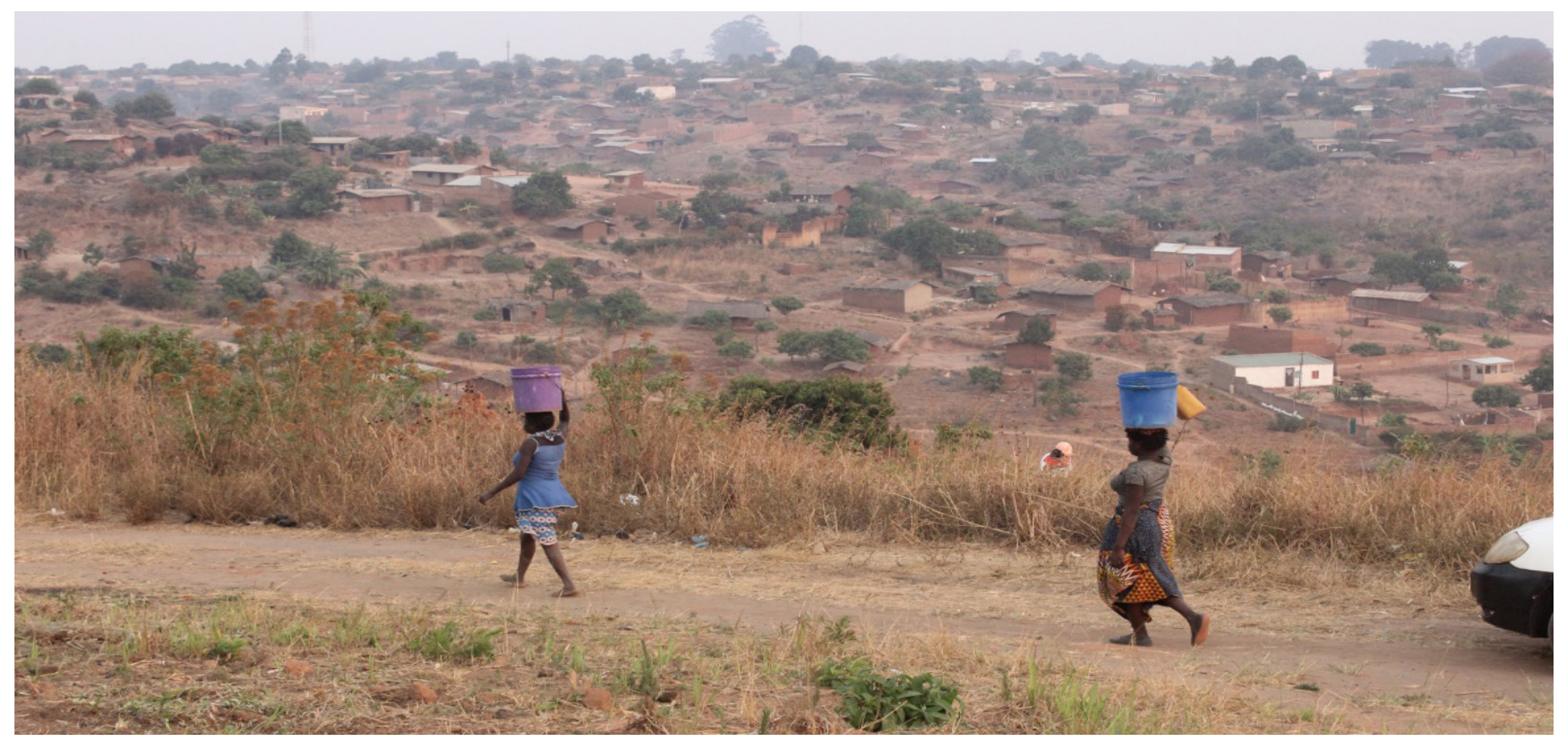

Figura 2: Parte do bairro' Nzinge.

Fonte: Imagem captada pelos autores, em 2021. 
Observa-se na imagem acima uma área de edificação desordenada, sob ruas sinuosas e de ocupação indiscriminada dos compartimentos do relevo. Observam-se também mulheres com baldes de água na cabeça, o que revela que parte das famílias não dispõe água potável nas habitações. As mulheres e raparigas são particularmente as mais afetadas pelo acesso inadequado à água.
A partir de dados cartográficos, observa-se, em 2021, o aumento da área de edificação não planeada. As áreas de edificação não planeada estão localizadas tanto junto ao centro da cidade como nas áreas de expansão localizadas na periferia (Vide Fig. 3).

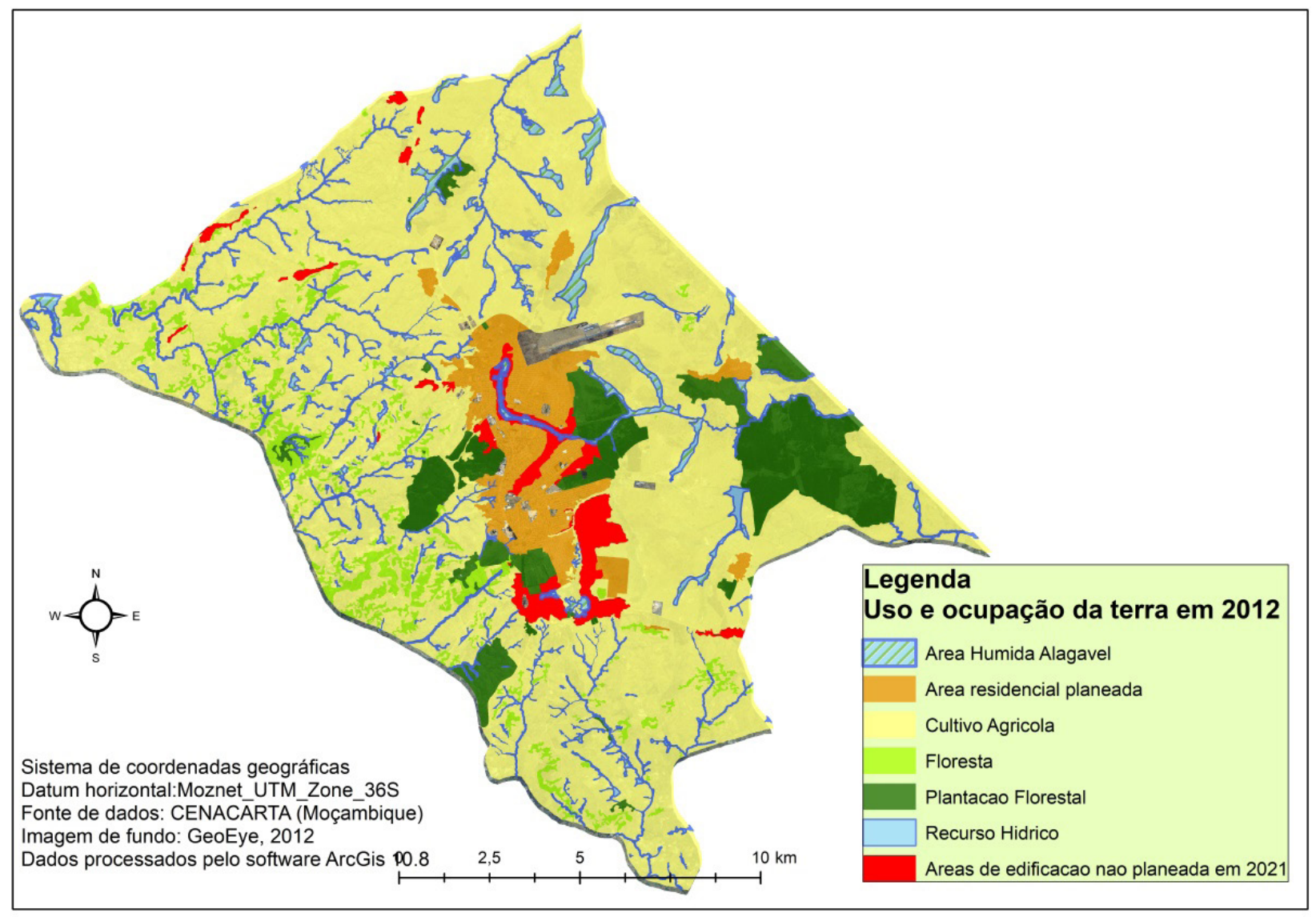

Figura 3: Parte do bairro `Nzinge.

Fonte: Imagem captada pelos autores, em 2021 
Observa-se na imagem acima uma área de edificação desordenada, sob ruas sinuosas e de ocupação indiscriminada dos compartimentos do relevo. Observam-se também mulheres com baldes de água na cabeça, o que revela que parte das famílias não dispõe água potável nas habitações. As mulheres e raparigas são particularmente as mais afetadas pelo acesso inadequado à água.

Caomba (2018) assinala como fatores que influenciaram a ocupação das áreas inundáveis (Fig. 4), nomeadamente: a falta de um plano de estrutura urbana, o crescimento do mercado informal de terras, as vantagens da localização das planícies aluviais próxima do centro da cidade e a fraca expansão territorial dos serviços básicos urbanos, de água, de energia e de transporte público urbano. Para esse autor, os aglomerados habitacionais precários localizados nas áreas inundáveis resultaram da conversão de parcelas de uso agrícola, bem como a adjacência ao centro da cidade e o custo "acessível" de aquisição informal de parcelas de terra figuram como os principais fatores que influenciaram a dimensão geográfica das edificações por esse segmento da população.

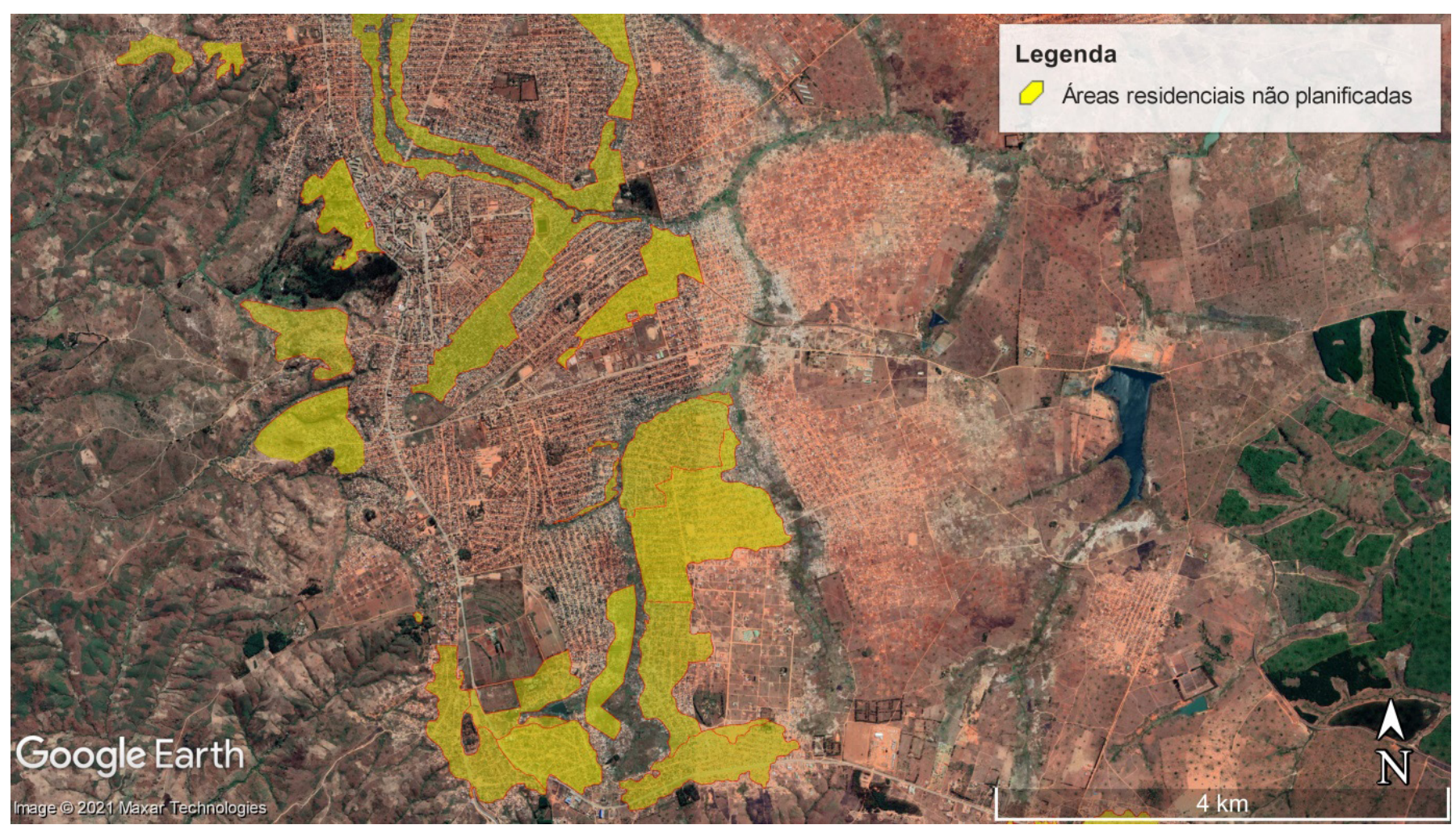

Figura 4: Implantação de residências por ocupação espontânea, não precedida de parcelamento, tanto em áreas inundáveis como em áreas de declive acentuado. A ocupação de áreas inundáveis pelo uso habitacional é observável tanto junto à área central, como também nas áreas de expansão localizadas na periferia.

Fonte: Google Earth, em 2021. 
Aponta-se a acessibilidade e a adjacência ao centro da cidade como fatores decisivos na estruturação espacial do uso residencial, particularmente. Ademais, a análise da forma de ocupação do território entre 2005 e 2021 (Fig. 5), com auxílio de imagens do Google Earth e complementada com observações de campo, possibilita identificar a prevalência da ocupação espontânea, pouco estruturada espacialmente, sem observância estrita de elementos estruturantes e sem respeitar o património ambiental. Portanto, a gestão da terra posta em prática, diante da forte pressão do uso habitacional por novas parcelas de terra, tem resultado na ocupação indiscriminada do meio biofísico, com realce para os terrenos contíguos ao centro da cidade. Aponta-se aqui a ausência de estratégias preventivas de orientação da ocupação do território.

Portanto, nota-se que as áreas junto aos vales estão sendo largamente ocupadas para fins habitacionais, diante da ausência de estratégias preventivas para uma ocupação mais racional. Essas margens das linhas de água outrora constituíam zonas destinadas ao desenvolvimento da horticultura, com importância na diversificação das fontes de rendimento para determinados segmentos da população. A organização de hortas comunitárias possibilitaria a criação de projetos de inclusão social. Contrariamente ao que se observa atualmente em alguns pontos do Município da cidade de Lichinga, as áreas junto aos canais de drenagem natural são espaços onde se incentiva a indução de processos de evapotranspiração, ao que se enquadra a implantação de zonas agrícolas, uma das tipologias da Infraestrutura Verde.

Em relação à urbanização e a resultante forma de ocupação do território na cidade de Lichinga, Caomba (2018) também constata a ocupação descontrolada da terra, associado a um padrão de edificação predominantemente horizontal e informal, fundamentalmente baseada em autoconstruções. As áreas fortemente concorridas para as autoconstruções informais na cidade de Lichinga são as planícies de inundação, localizadas junto ou que circundam o centro da cidade/cidade de cimento. Segundo ainda o autor, essas planícies de inundações outrora constituíram a maior cintura verde da cidade e os seus principais usos eram a caça e a atividade agropecuária de subsistência.
Realça-se que os problemas ambientais apontados, relacionados com a forma de ocupar o território, ocorrem diante da prevalência da desarticulação entre o Município e as autoridades comunitárias (régulos e Secretários de bairro) quanto à alocação e controlo de parcelas de terra para fins habitacionais, revelando, no seu conjunto, uma ineficácia dos mecanismos de controle do acesso à terra e orientação da ocupação do território, por parte do Município como entidade com competência na gestão territorial.

Ademais, perante situações em que a expansão do uso habitacional compromete as áreas agrícolas e florestais, como se pode compreender a partir da observação da ocupação entre 2005-2020 (Fig. $5)$, a partir de Carvalho (2000), Masquete (2018b) secunda que essa realidade está associada a não valorização das funções rurais na cidade. Nesse sentido, defende-se que se assuma o rural como modo de vida com possibilidades de integração na cidade e, por conseguinte, as áreas agrícolas e florestais como parte integrante da cidade, havendo a necessidade de induzir e definir, para elas, um modelo específico de ordenamento.

Observa-se na imagem acima um processo de expansão do uso habitacional que ocorre à custa retirada da cobertura vegetal (florestas de pinho), bem como da ocupação dos fundos de vale, áreas inundáveis, outrora áreas destinadas ao desenvolvimento da agricultura.

Processos de ocupação racional do território são guiados pela priorização da manutenção dos processos naturais e do equilíbrio biológico, ao que corresponde identificar os espaços de incentivo e restrição à ocupação (SCHUTZER, 2012).

Para Caomba (2018), são fatores que reproduzem o insucesso da gestão territorial em Moçambique a escassez de quadros especializados em matéria de planeamento e gestão territorial, a falta de fundos, o sistema duplo de governação territorial, a corrupção e o desperdício, tanto de recursos e materiais como humanos, a par do crescimento de mercado informal de terras.

Diante da ocupação desordenada, realidade que prevalece e se reproduz na cidade de Lichinga, o ordenamento do território deve estar voltado para atenuar deficiências ou aproveitar as potencialida- 


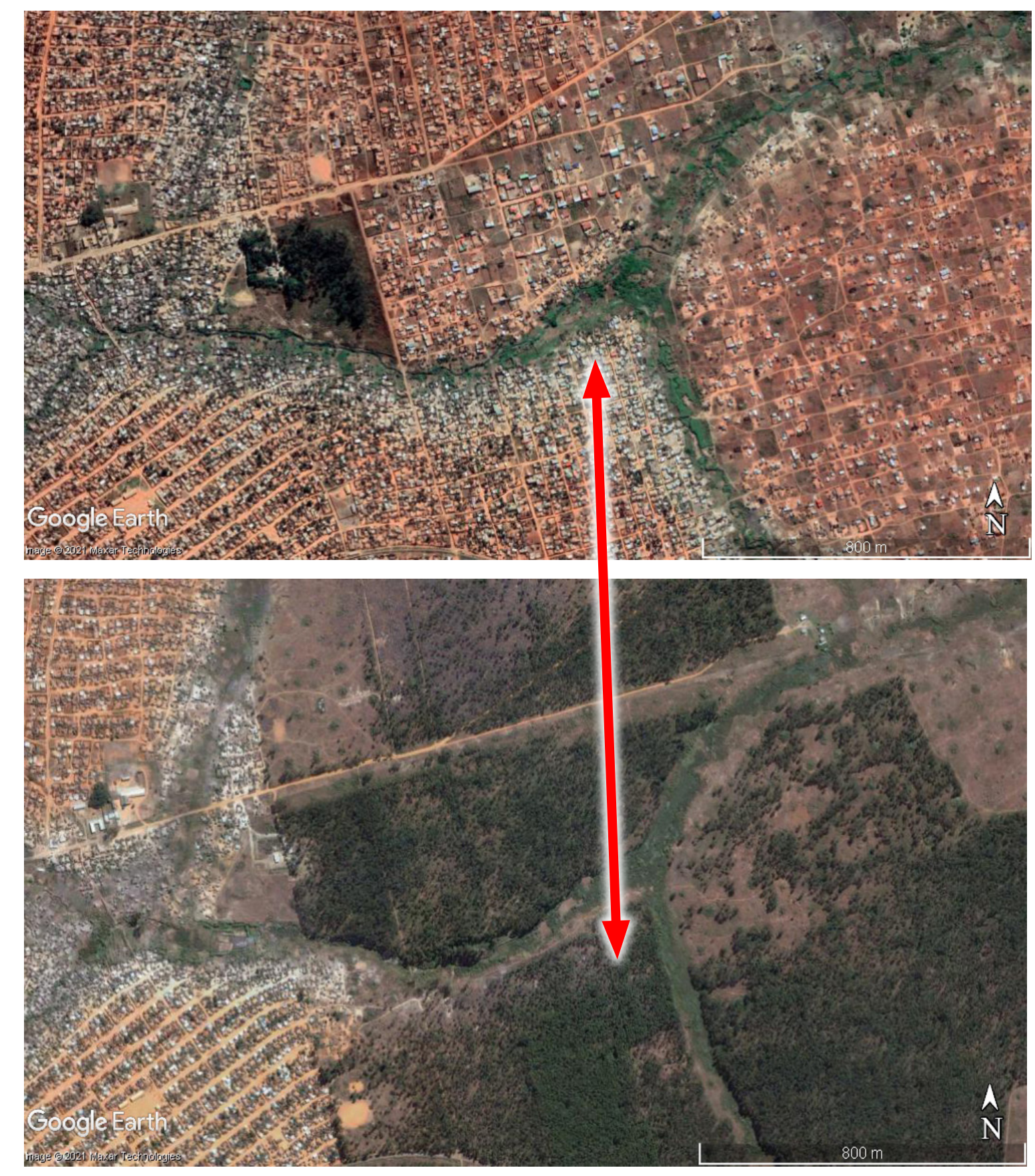

Parte da cidade de Lichinga, em 2021.

Parte da cidade de Lichinga em 2005

Figura 5: Dinâmica da ocupação do território na cidade de Lichinga, entre 2005 e 2021 (parte dos bairros Cerâmica, Namacula e Chiulugo).

Fonte: Imagens obtidas do Google Earth, 2005 e 2021, pelos autores, em 2021. 
des, ao que corresponde respeitar e valorizar os elementos da estrutura biofísica presentes no território, procurando constituir, a partir deles, uma estrutura verde, articulada, garantindo funcionalidade e conforto ambiental. Contudo, os elementos identificados com potencialidade para constituir estrutura ecológica nem sempre surgem organizados em rede, nem sempre constituem estrutura, perante ocupações edificatórias que não a respeitaram (CARVALHO, 2009).

Assim, em observâncias às características da compartimentação do relevo do Município da Cidade de Lichinga, apontam-se determinadas tipologias de Infraestrutura Verde que podem ser implantadas, concretamente: rede de corredores verde, cinturão verde e o estabelecimento de parques/jardins em lagoas pluviais (QUINTÃO, 2014; SOLARE, 2020).
O Parque/jardim em lagoa pluvial: a lagoa pluvial é um compartimento de relevo que funciona como bacia de retenção, recebendo o escoamento superficial de outros sistemas, onde a água pluvial permanece retida na estrutura. Concretamente, a partir do aproveitamento racional da sua área adjacente (vide Fig. 6), essa pode ser usada para o fomento de parques ou jardins, com possibilidades de influenciar na qualidade da água, o desenvolvimento de atividades de lazer, pedagógicas e económicas. Essas áreas são escolhidas pelas características da compartimentação do relevo, associado ao facto de constituir uma represa, ao que se incentiva à indução da evapotranspiração.

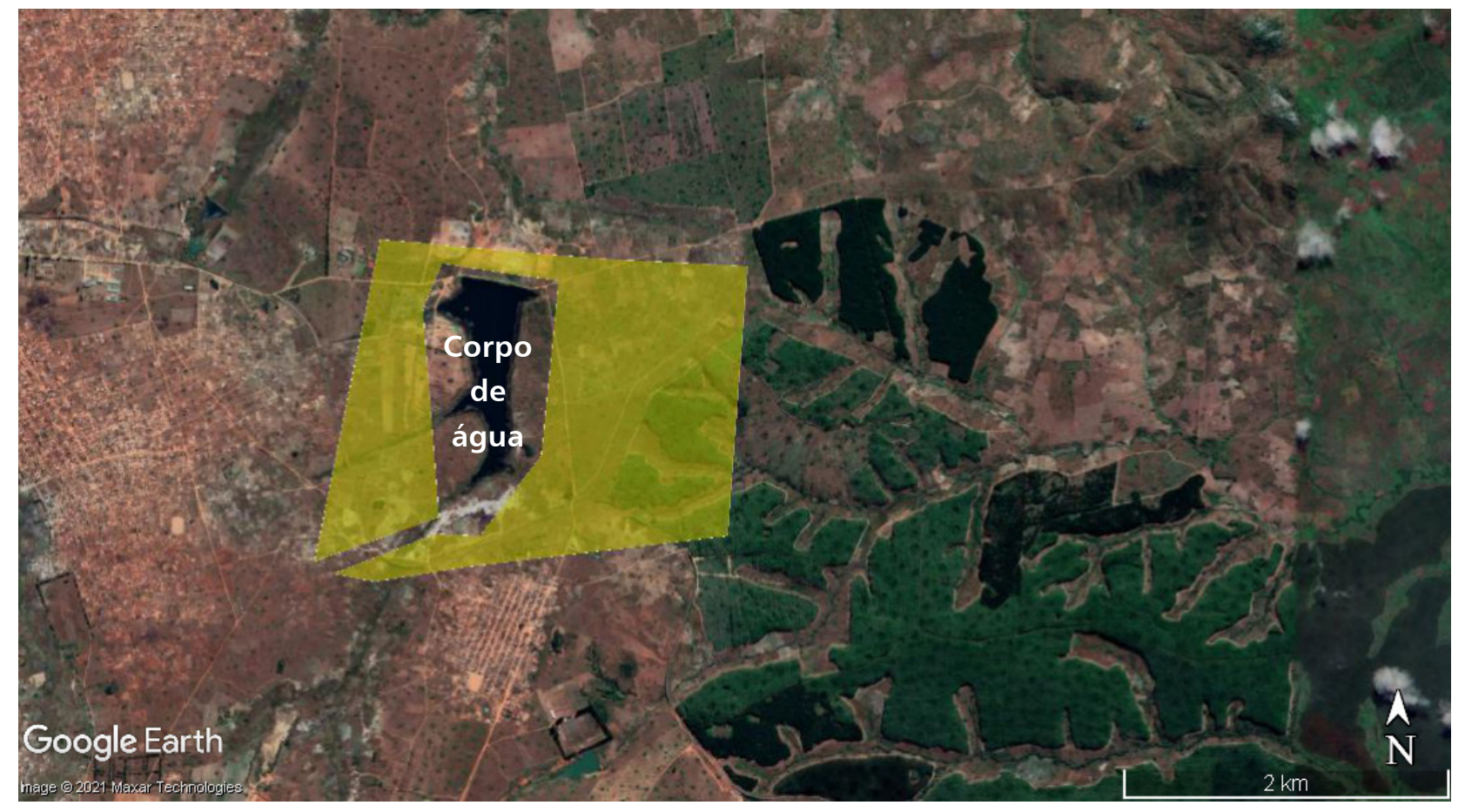

Figura 6: Área adjacente à represa como proposta para implantação de parque/jardim Fonte: Imagens obtidas do Google Earth, 2021, pelos autores, em 2021. 
Localizado no Brasil, concretamente na cidade de Campinas, o Parque Taquaral é um dos exemplos do melhor aproveitamento da compartimentação do relevo para implantação de um parque/jardim. A importância dos parques é assinalada por ser multifuncional, com destaque nas funções ambientais, pedagógicas, turísticas e de lazer.

O Cinturão Verde trata-se de espaço territorialmente demarcado, com a função de conservar e/ou preservar os recursos naturais e/ ou culturais a ele associado, utilizado como estrutura para o desenvolvimento e a preservação de ecossistemas naturais, podendo ter função produtiva, recreativa, ecológica ou de controlo do crescimento da área (áreas agrícolas e florestas urbanas fazem parte do cinturão verde da cidade, podendo ser implantadas nos polígonos assinalados pela Fig. 6). Por outro lado, os corredores verdes constituem sistemas de terrenos com base em elementos lineares existentes na paisagem (tal como vias e linhas de água), com funções ecológicas, recreativas, culturais, estéticas ou para outros fins compatíveis com o conceito de utilização sustentável da terra. As áreas potenciais para delimitação de corredores verdes na paisagem são aquelas relacionadas ao sistema viário principal e às áreas de preservação permanente de cursos de água, como assinaladas na Fig. 8.

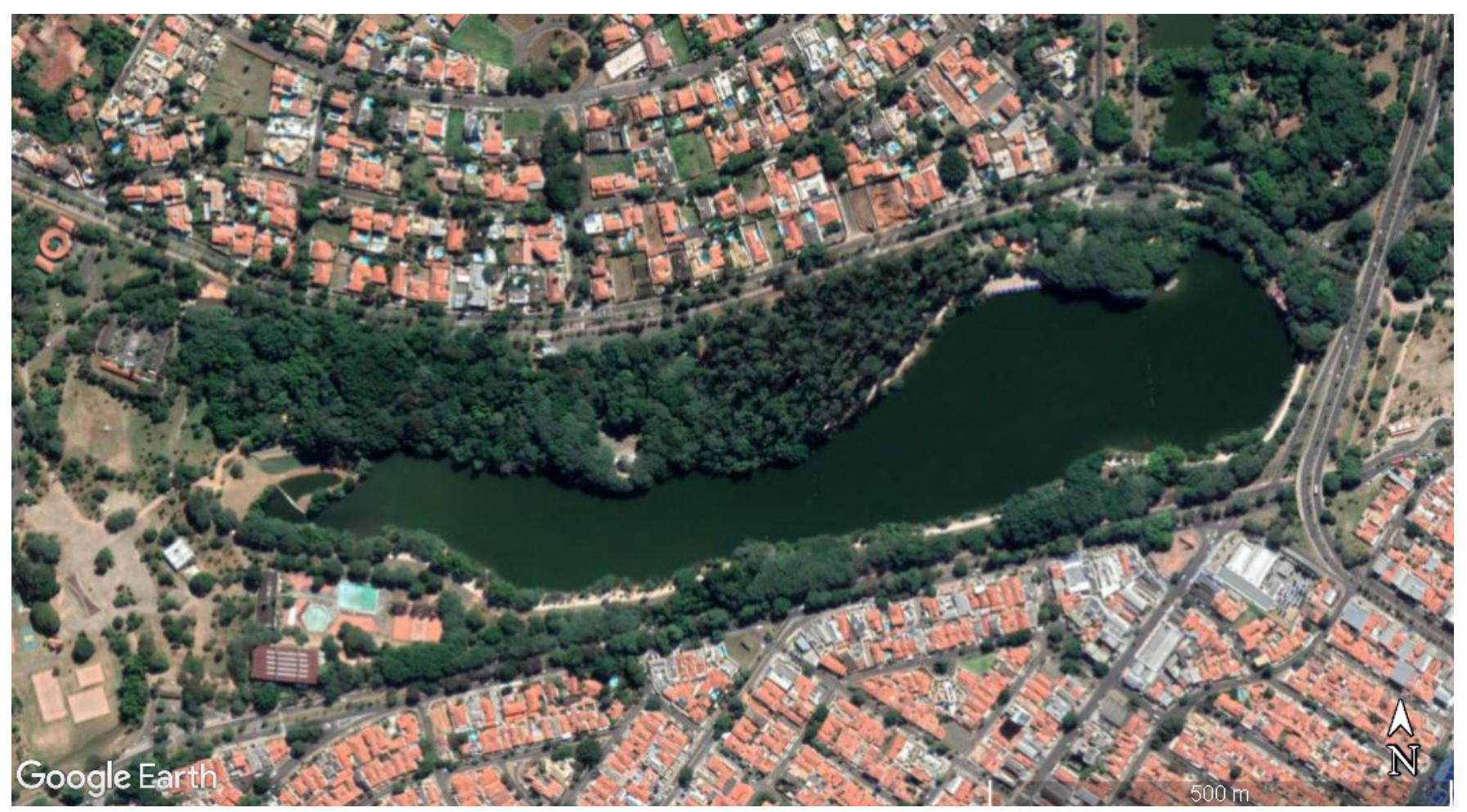

Figura 7: Vista do Parque Taquaral, localizado na cidade e Campinas, Brasil. Fonte: Imagem do Google Earth, 4/2020, obtida pelos autores, em 2021. 


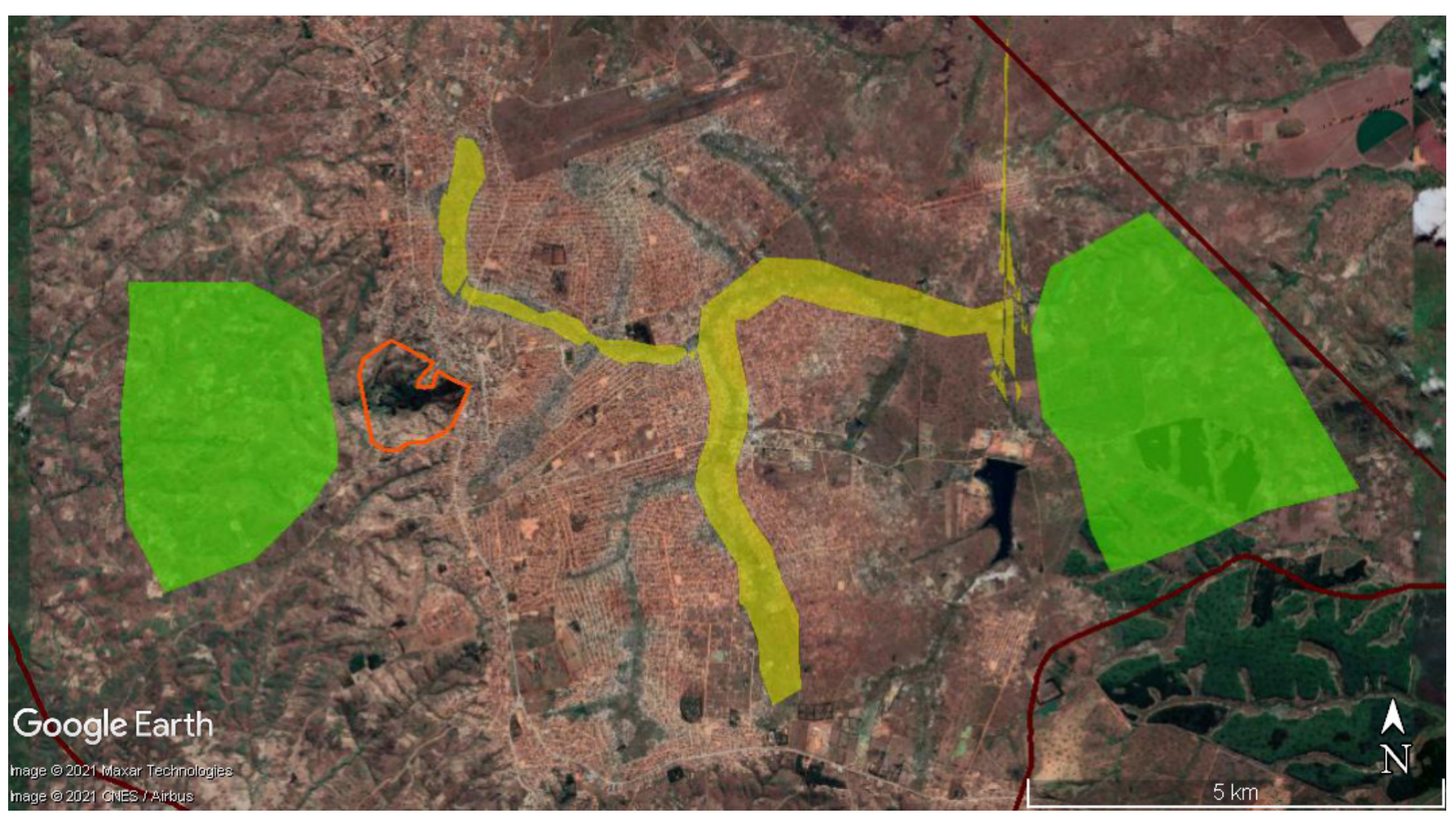

Figura 8: Algumas áreas potenciais para a implantação de zonas agroflorestais e agrícolas na cidade de Lichinga, valorizadas como tipologias da Infraestrutura Verde. A edificação em áreas inundáveis eleva a vulnerabilidade da população carenciada.

Legenda:

- Limite da Cidade de Lichinga. - Zona agrícola/horticultura (proposta).
- Zona Agroflorestal (proposta).

- ZIT de Lichinga1.

Fonte: Imagem do Google Earth, 8/2021, obtida pelos autores, em 2021.

1 Ao abrigo do Decreto n 71/2010, de 31 de Dezembro, foi declarada na cidade de Lichinga uma zona de interesse turístico, denominada Zona de Interesse Turístico de Lichinga, abreviada por ZITL. A ZITL situa-se nos bairros e Sanjala e 'Nzinje, é predominantemente uma floresta de pinho e ocupa 100 hectares. 
No momento atual é fundamental se apresentar estratégias de mitigação e adaptação em resposta às mudanças climáticas para se aumentar a resiliência dos assentamentos humanos, ao que se enquadra uma proposta centrada na implantação da Infraestrutura Verde como mecanismo para identificar, proteger e produzir espaços verdes integrados e influenciar no ordenamento e desenvolvimento do território.

\section{Considerações Finais}

Diante das limitações que concorrem para que grande parte das Autarquias em Moçambique não tenha efetivamente o Plano de Estrutura Urbana, considera-se fundamental integrar a Infraestrutura Verde no modelo de desenvolvimento territorial das cidades e vilas, particularmente, como instrumento do quadro legal para orientar as intervenções antrópicas.

O potencial da Infraestrutura Verde para como instrumento de orientação e controlo da forma de ocupação do território está assente na possibilidade de definir e delimitar, preventivamente as áreas "non aedificandi", constituindo, assim, meio para viabilizar sistemas de ocupação e uso da terra que protegem as áreas frágeis ou ambientalmente sensíveis, a conservação da natureza e da biodiversidade e a conservação das áreas com potencialidades produtivas.

O padrão de urbanização e a resultante forma de ocupação do território nas cidades moçambicanas revelam a ausência da implementação de instrumentos que limitam a edificação em áreas inundáveis ou com solos de alto potencial produtivo, a título de exemplos. Portanto, diante da ocorrência de processos de expansão da área urbanizada que desconsidera as potencialidades e limitações da base biofísica, a Infraestrutura Verde é assumida como instrumento preventivo de orientação da ocupação do território, particularmente por influenciar na redução das possibilidades de implantação do uso habitacional em áreas ambientalmente sensíveis.

Há necessidade de o quadro legal assumir a obrigatoriedade de definir e delimitar a Infraestrutura Verde Municipal como instrumento de ordenamento territorial, com a finalidade de orientar a edifica- ção, conservar as áreas com alto potencial produtivo e proteger as áreas de risco ambiental.

Sublinha-se que a delimitação e reserva de zonas com potencialidades agrícolas na cidade, uma tipologia da Infraestrutura Verde, constitui meio de incentivo ao fortalecimento da agricultura na cidade e sua valorização como estratégia de emponderamento da mulher, especificamente.

Uma vez que a Infraestrutura Verde proporciona serviços ambientais essenciais para a sustentabilidade da cidade e comunidades, é importante que as entidades com competência no planeamento e gestão do território identifiquem e priorizem áreas específicas para sua implantação, por tipologia de Infraestrutura Verde. A identificação de áreas prioritárias, e a seleção das respectivas tipologias de Infraestrutura Verde, deve ser efectuada a partir de uma abordagem colaborativa e participativa, dando foco à implantação planeada em áreas consideradas "de expansão". Contudo, a participação dos régulos e Secretários de bairro é indispensável, na medida em que constituem atores sociais com forte ingerência no acesso à terra formal ou na formalização do informal.

A delimitação das áreas para implantação da Infraestrutura Verde deverá observar as características da base biofísica do território e levar em consideração os problemas ambientais prevalecentes, bem como considerar os interesses e preocupações dos segmentos da população.

Uma das atuais limitações em Moçambique é que o quadro legal sobre o ordenamento do território não estabelece de forma explícita a necessidade de identificação, delimitação e implantação da Infraestrutura Verde Municipal como instrumento de caráter obrigatório. Há necessidade de enquadrar a Infraestrutura Verde nos instrumentos de ordenamento do território com a finalidade de orientar a edificação, conservar as áreas de alto potencial produtivo e a proteção de áreas de risco ambiental da cidade.

Contudo, aponta-se como lacuna do presente trabalho a falta de aplicação da metodologia proposta para uma dada cidade, com a participação dos atores em referência, concretamente por ausência de recursos financeiros para tal. A Proposta que aqui se apresenta 
constitui um projecto ainda por implementar com vista à delimitação da Infraestrutura Verde a partir de uma abordagem colaborativa e participativa.

\section{ReferênCIAS BibliográficAS}

ALVES, Tânia Daniela Monteiro. A estrutura ecológica urbana no modelo da rede estruturante da cidade. Dissertação de Mestrado, Universidade de Aveiro. 2009. Brasil. Estatuto da cidade (2001).

AUSTIN, Gary. Green infrastructure for landscape planning: Integrating human and natural systems. Routledge, New York, 2014.

BELIK, Walter. A mobilização empresarial pelo combate à fome. In: SILVA, José Graziano da; GROSSI, Mauro Eduardo Dei; FRANÇA, Galvão de (orgs.). Fome Zero: A experiência brasileira. Brasília: MDA, 2010. p. 111-140.

CAOMBA, David Paulo António. (2018). Ocupações informais do solo urbano em

Moçambique: análise dos fatores de motivação e do risco de ocupação das planícies de inundação na cidade de Lichinga. Tese de doutoramento, Universidade de Minho. http://hdl.handle.net/1822/56336

CARVALHO, Jorge. Ordenar a cidade. Coimbra, Quarteto Editora. 2003.

CARVALHO, Jorge. Matriz para estruturação do território. $15^{\circ}$ Congresso da APDR. Praia, Cabo Verde 2009.

CARVALHO, Jorge. Um caminho para a melhoria da prática urbanística. UEst, Jorge Carvalho Urbanistas.2018.HERZOG

Cecília; RIZZI, Daniela; FERRAZ, Victor. "Soluções baseadas na Natureza: por cidades mais verdes, resilientes e inclusivas". ArchDaily Brasil. 2021. Acessado a 2 de Agosto de 2021. < https://www.archdaily.com.br/br/963861/solucoes-baseadas-na-natureza-por-cidades-mais-verdes-resilientes-e-inclusivas > ISSN 0719-8906

COMISSÃO EUROPEIA. Relatório da comissão ao Parlamento Europeu, ao Conselho, ao Comité Económico e Social Europeu e ao Comité das Regióes: avaliação dos progressos na aplicação da estratégia da UE para a Infraestrutura Verde. Bruxelas. 2019. Disponível em: https://eur-lex europa.eu/legal-content/PT/TXT/PDF/?uri=CELEX:52019DC0236\&qid $=1562053537296$

FERREIRA, José C.; MACHADO, João R. Infra-estruturas verdes para um futuro urbano sustentável. O contributo da estrutura ecológica e dos corredores verdes. Revista LAB VERDE，(1), 69-90. https://doi.org/10.11606/issn.2179-2275.v0i1p69-90

FRANCO, M. (2010). Infraestrutura Verde em São Paulo: o caso do Corredor Verde Ibirapuera-Villa Lobos. Revista LABVERDE, (1), 135-154. https://doi.org/10.11606/issn.21792275.v0i1p135-154

HERZOG, C; Rosa, L. (2010). Infraestrutura Verde: Sustentabilidade e resiliência para a paisagem urbana. Revista LABVERDE, (1), 92-115. https://doi.org/10.11606/issn.21792275.v0i1p92-115

INSTITUTO NACIONAL DE ESTATÍSTICA-DELEGAÇÃO PROVINCIAL DE NIASSA. Folheto provincial 2020. NE. 2020

MINISTÉRIO DE TERRA, AMBIENTE E DESENVOLVIMENTO RURAL. Agenda Estratégica 2019 -2035 e Programa Nacional de Florestas. MITADER. 2019
PROGRAMA DAS NAÇOES UNIDAS PARA OS ASSENTAMENTOS HUMANOS (ONU-Habitat). International Guidelines on Urban and Territorial Planning. Nairóbi, ONU-Habitat. 2015.

QUINTAS, Andreia V. Génese e evolução dos modelos de Estrutura Verde Urbana na estratégia de desenvolvimento das cidade, 153-167. 2014. Disponível em: http://bdigital.ufp.pt/bitstream/10284/4540/1/ART.153-167.pdf.

SCHUTZER J. G. (2012). Cidade e meio ambiente: a apropriação do relevo no desenho ambiental urbano. São Paulo: Edusp. 2012.

SOLERA, Maria Lúcia; Machado, Aline R.; CAVANI, Ana c. M.; SOUZA, Caroline A.;

LONGO, Mariana H. C.; VELASCO, Giuliana Del n.; IKEMATSU, Priscila; AMARAL, Raque D. A. M (Orgs). Guia Metodológico para Implantação de Infraestrutura Verde. São Paulo: Fundação Apoio ao Instituto de Pesquisas Tecnologicas - FIPT, 2020.

\section{Júlio Ambrósio Masquete}

Universidade Rovuma. Extensão de Niassa-Departamento de Geociências

Avenida Samora Machel, 219, CP 4. Lichinga, Moçambique

https://orcid.org/0000-0002-9982-264X

\section{Goldfredy Manuel Chitile Chande}

Universidade Rovuma . Faculdade de Ciências Sociais

Avenida Josina Machel, 256, CP 544, Nampula, Moçambique

https://orcid.org/0000-0003-1803-333X

goldschande@yahoo.com.br

Nota do editor:

Recebido em: 01/06/2021

Aprovado em: 20/10/202 